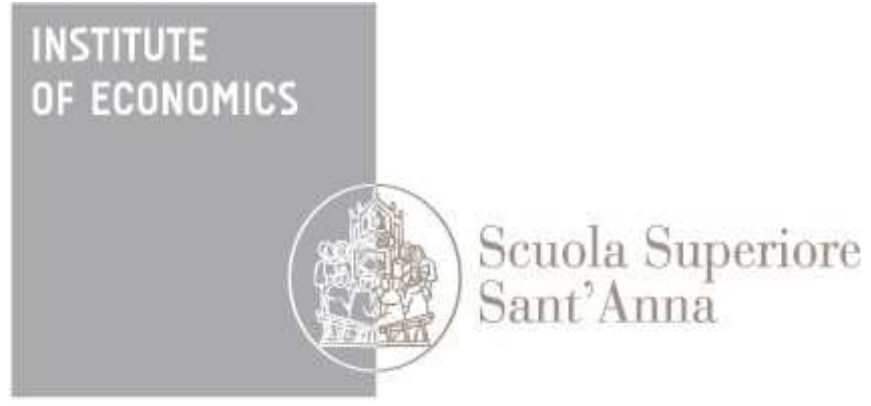

LEM | Laboratory of Economics and Management

Institute of Economics

Scuola Superiore Sant'Anna

Piazza Martiri della Libertà, 33 - 56127 Pisa, Italy ph. +3905088.33 .43$

institute.economics@sssup.it

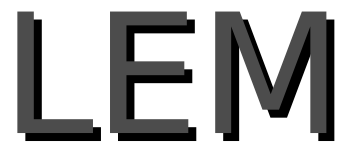

Working Paper Series

\title{
The Short- and Long-Run Damages of Fiscal Austerity: Keynes beyond Schumpeter
}

\author{
Giovanni Dosi * \\ Mauro Napoletano $\S^{*}$ \\ Andrea Roventini ${ }^{* \S}$ \\ Tania Treibich ${ }^{\circ}$ q* \\ *Institute of Economics and LEM, Scuola Superiore Sant'Anna, Pisa, Italy \\ ${ }^{\S}$ OFCE and SKEMA Business School, Sophia-Antipolis, France \\ - Maastricht University, the Netherlands \\ "University of Nice-Sophia Antipolis, France
}




\title{
The Short- and Long-Run Damages of Fiscal Austerity: Keynes beyond Schumpeter
}

\author{
Giovanni Dosi*1, Mauro Napoletano ${ }^{2,1}$, Andrea Roventini ${ }^{1,2}$ and Tania \\ Treibich $^{3,4,1}$ \\ ${ }^{1}$ Scuola Superiore Sant'Anna, Pisa (Italy) \\ ${ }^{2}$ OFCE and SKEMA Business School, Sophia-Antipolis (France) \\ ${ }^{3}$ Maastricht University (the Netherlands) \\ ${ }^{4}$ University of Nice-Sophia Antipolis (France)
}

October 30, 2014

\begin{abstract}
In this work we analyze the short- and long-run effects of fiscal austerity policies, employing an agent-based model populated by heterogeneous, boundedly-rational firms and banks. The model, in line with the family of "Keynes+Schumpeter" formalism, is able to account for a wide array of macro and micro empirical regularities. In particular, it endogenously generates self-sustained growth patterns together with persistent economic fluctuations punctuated by deep downturns. On the policy side, we find that austerity policies considerably harm the economy, by increasing output volatility, unemployment, and the incidence of crises. In addition, they depress innovation and the diffusion of new technologies, thus reducing long-run productivity and GDP growth. Finally, we show that "discipline-guided" fiscal rules are self-defeating, as they do not stabilize public finances, but, on the contrary, they disrupt them.
\end{abstract}

Keywords: agent-based model, fiscal policy, economic crises, austerity policies, disequilibrium dynamics

JEL Classification: C63, E32, E6, G01, G21, O4

\footnotetext{
*Corresponding author: Institute of Economics (LEM), Scuola Superiore Sant'Anna; Piazza Martiri della Libertà 33 - I-56127 Pisa (Italy); gdosi@sssup.it.
} 


\section{Introduction}

In this work, we employ the Keynes+Schumpeter $(\mathrm{K}+\mathrm{S})$ agent-based model (Dosi et al., 2010, 2013, 2014) to compare short- and long-run effects of Keynesian fiscal policies visà-vis austerity rules.

The Great Recession has been the most severe downturn of the last eighty years, resulting into higher government deficits and debt-to-GDP ratios in many advanced countries. In the European Monetary Union, the policy response to such crisis-induced high debt has been the introduction of fiscal austerity, based on the belief that fiscal austerity is the main recipe to kill two birds with one stone: putting government debt growth under control and restoring economic growth. The historical experience has proved that this belief is manifestly wrong: the GDP of most European countries is still below the precrisis level, and most of them are on the edge of a triple-dip recession. Even in the more successful economies (e.g. Germany), output is still far away from its potential.

Then, why were such disastrous policies implemented? One explanation is that they were inspired by misleading macroeconomic theories. Indeed, if standard DSGE models, grounded on the assumption of infinity-lived, optimizing rational agents endowed with rational expectations, work well in "normal times", when the economy experience mild fluctuations, they do not even admit the possibility of deep downturns such as the Great Recession (Stiglitz, 2014a; Krugman, 2011). As a consequence, those DSGE models do not provide any useful advice to policy makers aiming at restoring steady growth, or, even worse, they support wrong policy choices. For example, in spite of a growing body of empirical research showing that fiscal multipliers are constantly higher than one during recessions (see e.g. Auerbach and Gorodnichenko, 2012) or when credit markets are under stress (Ferraresi et al., 2014), their systematic under-estimation in standard models explains why austerity policies have hit the European economies so hard (Blanchard and Leigh, 2013). ${ }^{1}$

More generally, the recent economic crisis represents a crisis for macroeconomic theory (Kirman, 2010b; Stiglitz, 2011; Dosi, 2012). The design of effective economic policies requires a reconstruction of macroeconomic theory (Stiglitz, 2014a), starting from models able to jointly account for both "normal" fluctuations and deep downturns (Stiglitz, 2011, 2014b), as well as for far-from-equilibrium dynamics triggered by the endogenous generation and non-linear transmission of non-Gaussian shocks. In that, the economy should be considered as a complex evolving system, wherein aggregate outcomes such as credit crunches, bankruptcy cascades, banking crises, and depressions emerge out of the

\footnotetext{
${ }^{1}$ The case for fiscal discipline has also be grounded on the myth of "expansionary austerity" (e.g. Alesina and Ardagna, 2010), as well as on the fear that levels of public debt higher than a supposed threshold of $90 \%$ of GDP would have harmed the growth potential of economies (Reinhart and Rogoff, 2010). The "expansionary austerity" hypothesis has been contradicted by a wealth of empirical evidence (cf. e.g. Guajardo et al., 2011). In the case of the $90 \%$ hypothesis, the results were grounded on debatable assumptions as well as on some mistakes in the treatment of data (Herndon et al., 2014).
} 
interactions occurring between heterogeneous agents (Farmer and Foley, 2009; Kirman, 2010a; Stiglitz, 2011; Dosi, 2012).

This is the starting point of the $\mathrm{K}+\mathrm{S}$ model (Dosi et al., 2010, 2013, 2014). The model is a bridge between Keynesian theories of demand generation and Schumpeterian theories of innovation and economic growth, with "Minskian" financial dynamics. It describes an economy composed of heterogeneous capital- and consumption-good firms, a labor force, banks, a Government, and a Central Bank. Capital-good firms perform $\mathrm{R} \& \mathrm{D}$ and produce heterogeneous machine tools. Consumption-good firms invest in new machines and produce a homogeneous consumption good. The latter type of enterprises finance their production and investments with their liquid assets and, if necessary with credit. Higher production and investment levels rise firms' debt, eroding their net worth and consequently increasing their credit risk. Banks, in turn, increase the level of credit rationing in the economy and force firms to curb production and investment, thus possibly triggering a recession. Bank failures can endogenously emerge from the accumulation of loan losses on banks' balance sheets. Banking crises imply direct bailout costs on the public budget and may therefore affect the dynamics of Government deficit and debt. The latter can also vary as a consequence of the change in tax revenues and unemployment subsidies over the business cycle.

Our model is rooted in the evolutionary tradition (Nelson and Winter, 1982), and belongs to the growing body of literature on macroeconomic agent-based models (Tesfatsion and Judd, 2006; LeBaron and Tesfatsion, 2008). ${ }^{2}$ The microeconomic foundations of the $\mathrm{K}+\mathrm{S}$ model are "realistic", i.e. close to how markets work and agents behave. First, we assume that the economy is characterized by pervasive information asymmetries. As a consequence, markets are not Pareto efficient (in line with the results in Greenwald and Stiglitz, 1986) and agents (firms, banks, etc.) are persistently heterogeneous. Second, our microfoundations are "behavioral" (Akerlof, 2002), i.e. they are grounded on micro empirical evidence. In such a framework, boundedly-rational agents interact without resorting to any ex-ante commitment to the reciprocal consistency of their actions, thus implicitly addressing the call by Solow (2008) for genuine micro-heterogeneity. Evolutionary, agentbased models like ours are concerned with the emergent properties of a simulated system in which heterogeneous agents' routinized behaviors lead to repeated interactions, which may occur close or very far from full-employment equilibria.

We empirically validate the model, showing that the statistical properties of simulated microeconomic and macroeconomic data replicate a rather long list of micro and macro empirical regularities. Moreover, we show the model is endogenously able to generate

${ }^{2}$ For germane ABMs, see e.g. Ciarli et al. (2010); Mandel et al. (2010); Russo et al. (2007); Delli Gatti et al. (2010); Ashraf et al. (2011); Battiston et al. (2012); Dawid et al. (2014a,b); Raberto et al. (2012); Salle et al. (2013) and the papers in Dawid and Fagiolo (2008) and Gaffard and Napoletano (2012). See also Fagiolo and Roventini (2012) for a critical comparison of policy analysis in DSGE and agent-based models. 
both mild and "deep" downturns. In that the $\mathrm{K}+\mathrm{S}$ model appears to be more successful than its DSGE counterparts, which do not generate major crises even when they are fed with exogenous fat-tailed shocks (more on that in Ascari et al., 2014).

Furthermore, we employ the model as a "computational laboratory" to compare shortand long-run impacts of an austerity rule à la European Stability and Growth Pact (SGP) and of Keynesian fiscal policies, where automatic stabilizers are free to smooth business cycle fluctuations. We find that when the SGP rule is in place, the economy is more volatile, average unemployment is higher and the economy is more likely to experience deep crises. The depressing effects of austerity extend also to the long-run. More precisely, by curbing aggregate demand, the SGP rule considerably reduces consumption-good firms' investment in new machine tools, slowing down technology diffusion, and capital-good firms' R\&D expenditures, reducing the innovation rate of the economy. This entraps the economy into an absorbing state characterized by stagnant productivity and output growth. Finally, in line with the recent empirical evidence (see e.g. De Grauwe and Ji, 2013), the SGP austerity policy appears to be self-defeating, as the public debt to GDP ratio skyrockets, while under Keynesian fiscal policies it remains low and stable.

The rest of the paper is organized as follows. In Section 2 we present the model. Simulation results are reported in Section 3. Finally, Section 4 concludes.

\section{The Model}

The basic structure of the full-fledged Keynes+Schumpeter (K+S, cf. Dosi et al., 2010, 2013, 2014; Napoletano et al., 2012) model is portrayed in Figure 2. The economy is composed of $F_{1}$ capital-good firms, (denoted by the subscript $i$ ), $F_{2}$ consumption-good firms (denoted by the subscript $j$ ), $L^{S}$ consumers/workers, $B$ commercial banks (denoted by the subscript $k$ ), a Central Bank and the Government sector. Capital-good firms invest in R\&D and produce heterogeneous machine-tools, whose productivity evolves over time. Consumption-good firms combine machines bought from capital-good firms and labor in order to produce an homogeneous product for consumers. The banks provide credit to consumption-good firms, collect firms' savings and buy Government bonds. The public sector levies taxes on firms' and banks' profits, pays unemployment benefits and bails banks out in case of banking crises. The Government can run deficits, issuing bonds, which are bought by the banking sector. Finally, the Central Bank fixes the baseline interest rate in the economy and the macroprudential regulatory framework.

Let us now sketch the main characteristics and dynamics of the $\mathrm{K}+\mathrm{S}$ model. A detailed description of the model is provided in Dosi et al. (2014). 


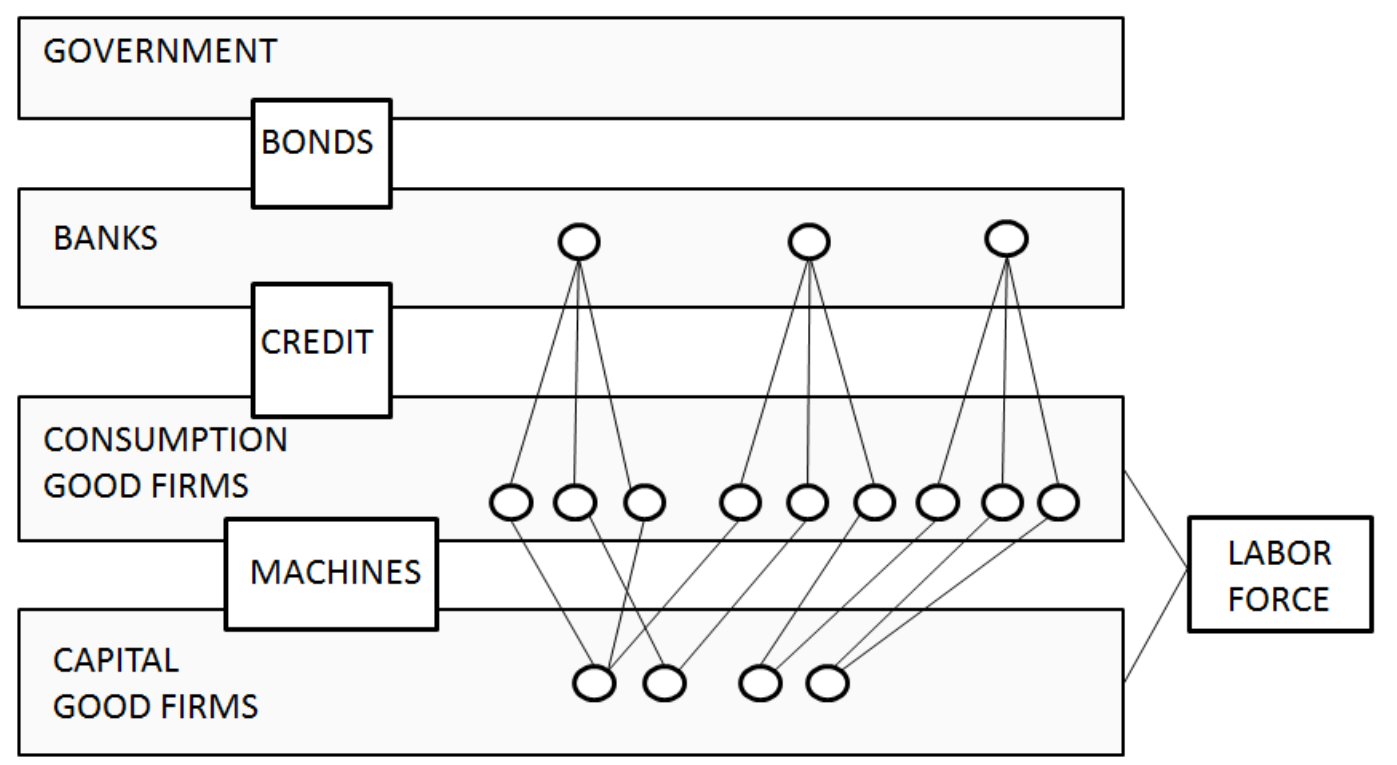

Figure 1: The structure of the Keynes+Schumpeter model

\subsection{The Timeline of Events}

In any given time period $(t)$, the following microeconomic decisions take place in sequential order:

1. Policy variables (e.g. capital requirement, tax rate, Central Bank interest rate, etc.) are fixed.

2. Total credit notionally providable by the banks to their clients is determined.

3. Machine-tool firms perform $\mathrm{R} \& \mathrm{D}$, trying to discover new products and more efficient production techniques and to imitate the technologies and the products of their competitors. They then signal their machines to consumption-good firms (under conditions of imperfect information).

4. Consumption-good firms decide how much to produce and invest. If internal funds are not enough, firms borrow from their bank. If gross investment is positive, consumption-good firms choose their supplier and send their orders.

5. In both industries firms hire workers according to their production plans and start producing. Consumption-good firms may get external finance from banks to pay for production (i.e., to advance wages).

6. The Government determines the amount of unemployment subsidies to allocate, possibly being limited by the fiscal rule.

7. Imperfectly competitive consumption-good market opens. The market shares of firms evolve according to their price competitiveness. 
8. Firms in both sectors compute their profits. If profits are positive, firms pay back their loans to their bank and deposit their net savings, if any.

9. Banks compute their profits and net worth. If the latter is negative they fail and they are bailed out by the Government.

10. Entry and exit take places. In both sectors firms with near zero market shares or negative net liquid assets are eschewed from the two industries and replaced by new ones.

11. Machines ordered at the beginning of the period are delivered and become part of the capital stock at time $t+1$.

At the end of each time step, aggregate variables (e.g. GDP, investment, employment) are computed, summing over the corresponding microeconomic variables.

\subsection{The Capital- and Consumption-Good Sectors}

The capital-good industry is the locus where innovation is endogenously generated in the economy. Capital-good firms develop new technologies or imitate the ones of their competitors in order to produce and sell more productive and cheaper machine tools that are supplied to consumption-good firms. Capital-good firms invest a fraction of their past sales in R\&D in order to discover new machines or copy existing ones. They produce machine-tools by employing only labor and set prices as a fixed mark-up over unit costs of production. Note that as consumption-good firms pay the machines in advance, capitalgood firms do not need credit to finance their production.

Consumption-good firms produce a homogeneous consumption good employing capital (composed of different vintages of machines) and labor under constant returns to scale. Desired production is fixed according to myopic demand expectations. ${ }^{3}$ Given the actual stock of inventories, if the capital stock is not sufficient to produce the desired production level, consumption-good firms invest in new machines in order to expand their production capacity. They also invest to replace old and obsolete machines according to a payback period rule. In such case, their production capacity does not change. As new machines embed state-of-the-art technologies, the labor productivity of consumption-good firms increases over time according to the vintages of machine present in their capital stock.

The capital-good market is characterized by imperfect information and "Schumpeterian" competition. Capital-good firms can have multiple customers, whereas consumptiongood firms only have one supplier (Cf. Figure 2). Machine-tool firms signal the price and productivity of their machines to their actual customers as well as to a set of potential

\footnotetext{
${ }^{3}$ As in our previous works (Dosi et al., 2006, 2008, 2010, 2013), firms are endowed with myopic expectations. In line with the experiments performed in Dosi et al. (2006), the simulation results do not significantly change when consumption-good firms follow more sophisticate expectation formation rules.
} 
new ones. Consumption-good firms choose in every period their supplier comparing the price and the production costs entailed by the machines they are aware of.

Consumption-good firms have to advance worker wages as well as pay the machines they ordered, thus they may need external financing. As capital markets are imperfect (e.g. Stiglitz and Weiss, 1981; Greenwald and Stiglitz, 1993; Hubbard, 1998), firms may be credit rationed, internal and external sources of finance are imperfect substitutes, and the Modigliani and Miller (1958) theorem does not hold. Thus the financial structure of firms matters, i.e. bank credit is more expensive than internal funds. To fund their production and investment plans, firms first use their stock of liquid assets, and the residual part represents their credit demand. If internal funds and credit are not enough, consumption-good firms cannot satisfy their desired level of production and investment. More specifically, the maximum amount of debt of firms is constrained by a loan-to-value ratio, which limits the maximum amount of debt each firm can sustain. Moreover, the credit supply of banks may not be sufficient to satisfy firms's credit demand (more details in Section 2.3). Credit-constrained firms first cut their investment and then downscale their production plans. Finally, firms pay an interest rate on their loans, which depends on the Central Bank interest rate $\left(r_{t}\right)$, as well as on firms' credit rating.

Imperfect information is the normal state of the consumption-good market (see Rotemberg, 2008, for a survey on consumers' imperfect price knowledge). As a consequence, consumers cannot instantaneously switch to the most competitive producer even if the good is homogeneous. Consumption-good firms fix their prices applying a variable markup on their production costs. The latter are given by the ratio between the nominal wage $\left(w_{t}\right)$ and the average labor productivity resulting from the machines employed in the production process. Mark-up dynamics are driven by the evolution of firms' market shares (in line with "customer market" models originally described by Phelps and Winter, 1970): firms increase their price whenever their market share is expanding. In turn, market shares evolve according to a "quasi replicator" dynamics: more competitive firms expand while firms with a relatively lower competitiveness level shrink .

At the end of every period, capital- and consumption-good firms compute their profits, pay taxes, and update their stock of liquid assets. If the latter is positive, they increase their bank deposits (consumption-good firms repay their debt first). If a firm's stock of liquid assets is negative or if its market share shrinks to zero, it goes bankrupt and exits the market. As we assume that the number of firms is fixed over time, each dead firm is replaced by a new entrant. ${ }^{4}$

\footnotetext{
${ }^{4}$ Furthermore, in line with the empirical literature on firm entry (Caves, 1998), we assume that entrants are on average smaller than incumbents, with the stock of capital of new consumption-good firms and the stock of liquid assets of entrants in both sectors being a fraction of the average stocks of the incumbents.
} 


\subsection{The Banking Sector}

In the model, money is endogenous as its supply depends on the lending activity of banks (among a vast body of literature, see e.g. Godley and Lavoie, 2007; McLeay et al., 2014). Commercial banks gather deposits and provide credit to firms. The number of banks is fixed and is related to the number of firms in the consumption-good sector. For simplicity, we assume that the network linking firms and banks is fixed over time (the bank-firm relationship holds both for deposits and credit). Following the empirical evidence on the skewness of the bank size distribution (Berger et al., 1995; Ennis, 2001), banks are assumed heterogeneous in the number of clients, which are drawn from a Pareto distribution.

The supply of credit by banks is a function of their equity. It is constrained by capital adequacy requirements inspired by Basel-framework rules (on a similar assumption cf. Delli Gatti et al., 2010; Ashraf et al., 2011; Raberto et al., 2012). Moreover, banks maintain a buffer over the mandatory level of capital, whose magnitude is strategically altered over the business cycle according to their financial fragility (Bikker and Metzemakers, 2005; Becker and Ivashina, 2014). ${ }^{5}$ Credit supply is thus impacted by changes in the banks' balance sheet, which itself is affected by bank profits net of loan losses. This creates a negative feedback loop from loan losses to changes in banks' equity with a reduction in the amount of credit supplied to firms in the next period.

Credit demand stems from consumption-good firms' financing needs net of their internal funds (see above). Banks allocate credit among their clients by ranking the applicants in terms of their creditworthiness, defined by the ratio between past net worth and past sales. Banks provide credit up to their credit supply ceiling. A firm's ability to obtain credit depends therefore on its financial status which determines its ranking, but also on the financial fragility of its bank.

Banks fix the interest rate on loans applying a mark-up on the Central Bank interest rate $\left(r_{t}\right)$, which is set in each period according to a Taylor rule (Howitt, 1992; Taylor, 1993):

$$
r_{t}=r^{T}+\gamma_{\pi}\left(\pi_{t}-\pi^{T}\right), \quad \gamma_{\pi}>1
$$

where $\pi^{T}$ and $r^{T}$ are the target inflation and interest rates and $\pi_{t}$ is the inflation rate of the period. ${ }^{6}$ Loan rates incorporate borrowers' idiosyncratic credit risk. More specifically, in every period, banks split their customers in four risk classes with increasing risk premia according to their position in the credit ranking. Firms' deposits are rewarded at the rate

\footnotetext{
${ }^{5}$ More precisely, following Adrian and Shin (2010), we proxy banks' fragility with the ratio between accumulated bad debt (i.e. loans in default) and bank assets (i.e. sum of the stocks of loans, Government bonds and reserves held by the bank). The detailed description of the banking sector can be found in Dosi et al. (2014).

${ }^{6}$ Notice that as the model is designed to account for both mild fluctuations and crises, deflation periods may endogenously emerge.
} 
$r_{t}^{D}$, banks' reserves at the Central Bank yield the reserves rate $r_{t}^{r e s}$, and Government bonds pay an interest rate $r_{t}^{b o n d s}$. The different interest rates are set so that $r_{t}^{D} \leq r_{t}^{r e s} \leq$ $r_{t}^{b o n d s} \leq r \leq r_{t}^{d e b}{ }^{7}$

At the end of the period, banks compute their profits $\left(\Pi_{k, t}^{b}\right)$ :

$$
\Pi_{k, t}^{b}=r_{c l, t}^{d e b} \text { Loans }_{k, t}+r^{\text {res }} \operatorname{Res}_{k, t}+r_{t}^{\text {bonds }} \text { Bond }_{k, t}-r^{D} \text { Depo }_{k, t}-\text { BadDebt }_{k, t}
$$

where Loans $_{k, t}$ are loans to firms, Res $k, t$ are the reserves deposited at the Central Bank, Bond $_{k, t}$ is the stock of Government bonds, Depo $k, t$ are firms' deposits, and BadDebt $t_{k, t}$ captures loans in default. Banks experience loan losses whenever one of their clients goes bankrupt and exits the market with a positive debt. Banks' profits net of taxes $\left(N e t \Pi_{k, t}^{b}\right)$ are then added to their net worth $\left(N W_{k, t}^{b}\right)$, which is equal to the difference between assets and liabilities:

$$
N W_{k, t}^{b}=\operatorname{Loans}_{k, t}+\operatorname{Res}_{k, t}+\operatorname{Bond}_{k, t}-\operatorname{Depo}_{k, t}+N e t \Pi_{k, t}^{b}
$$

Loan losses represent a negative shock to bank profits, which may become negative. If the net worth of the bank is not sufficient to cover such losses, the bank goes bankrupt. Whenever, a bank fails $\left(N W_{k, t}^{b}<0\right)$, the Government steps in and bails it out providing fresh capital. ${ }^{8}$ The cost of the public bailout $\left(\right.$ Gbailout $\left._{t, k}\right)$ is the difference between the failed bank's equity before and after the public intervention. We assume that the bank's equity after the bailout is a fraction of the smallest incumbent's equity, provided it respects the capital adequacy ratio.

\subsection{The Labor Market, Consumption and the Government Sec- tors}

The labor market does not feature any Walrasian clearing mechanism. The labor supply $L^{S}$ is fixed and inelastic to the wage rate $\left(w_{t}\right)$, which is determined by institutional and market factors. The indexation mechanism depends on the gap between actual and targeted inflation, and the dynamics of average productivity and of the unemployment rate:

$$
\frac{\Delta w_{t}}{w_{t-1}}=\pi^{T}+\psi_{1}\left(\pi_{t-1}-\pi^{T}\right)+\psi_{2} \frac{\Delta \overline{A B}_{t}}{\overline{A B}}-\psi_{t-1} \frac{\Delta U_{t}}{U_{t-1}}
$$

\footnotetext{
${ }^{7}$ Simulation results do not significantly change if the interest rate on bonds is higher than the policy rate fixed by the Central Bank $\left(r^{\text {bonds }} \geqslant r\right)$.

${ }^{8}$ We also run a series of Monte Carlo experiments in which a failed bank is acquired by the largest incumbent bank, instead of being saved by the Government. In such a case, the firm-bank network is altered by bank failures, which entails a change in the structure of the banking market, also increasing market concentration. The simulation results shown in section 3.3 are robust to this alternative setting.
} 
where $\overline{A B_{t}}$ is the average labor productivity, $U_{t}$ the unemployment rate, and $\psi_{1,2,3}>0$. As a consequence, both involuntary unemployment and labor rationing may emerge in the labor market.

Unemployed workers receive a subsidy $\left(w_{t}^{u}\right)$ which is a fraction of the current wage, i.e. $w_{t}^{u}=\varphi w_{t}$, with $\varphi \in[0,1]$. Given the total labor demand $L_{t}^{D}$, the total amount of unemployment subsidies to be paid by the Government $\left(G_{t}\right)$ is:

$$
G_{t}=w_{t}^{u}\left(L^{S}-L_{t}^{D}\right)
$$

We assume workers fully consume their income. ${ }^{9}$ Accordingly, aggregate consumption $\left(C_{t}\right)$ depends on the income of both employed and unemployed workers:

$$
C_{t}=w_{t} L_{t}^{D}+G_{t}
$$

Taxes paid by firms and banks on their profits are gathered by the Government at the fixed tax rate $t r$. Public expenditures are composed of the cost of public debt $\left(\right.$ Debt $\left._{t}^{\cos t}\right)$, of bank bailouts (Gbailout $t_{t}=\sum_{k=1}^{B}$ Gbailout $_{k, t}$ ) and the unemployment subsidies $\left(G_{t}\right)$. Public deficit is then equal to:

$$
\operatorname{Def}_{t}=\text { Debt }_{t}^{\text {cost }}+\text { Gbailout }_{t}+G_{t}-\text { Tax }_{t}
$$

If $D e f_{t}>0$, the Government has to issue new bonds, which are bought by banks according to their share in the total supply of credit. ${ }^{10}$ If the demand for bonds from the Government is higher than what banks are able to buy, the Central Bank steps in and buys the remaining debt. ${ }^{11}$ If $D e f_{t}<0$, the Government uses the surplus to repay its debt.

To repeat, the dynamics generated at the micro-level by decisions of a multiplicity of heterogeneous, adaptive agents and by their interaction mechanisms is the explicit microfoundation of the dynamics for all aggregate variables of interest (e.g. output, investment, employment, etc.). The model satisfies the standard national account identities: the sum of value added of capital- and consumption goods firms $\left(G D P_{t}\right)$ equals their aggregate production (in our simplified economy there are no intermediate goods). Total produc-

\footnotetext{
${ }^{9}$ The above is equivalent to assume that workers are credit constrained and therefore cannot engage in standard consumption smoothing. This is in line with the microeconomic empirical evidence suggesting that the consumption of most households tracks their income as their wealth is close to zero (see e.g. Wolff, 1998). Notice that the conclusions of the paper qualitatively hold as long as, in good Keynesian fashion (e.g. Kaldor, 1955), the propensity to consume out of profits is lower that that out of wages.

${ }^{10}$ Sovereign bonds are endogenously supplied by the Government according to its deficit, while banks' demand for bonds is accommodating supply, in the spirit of e.g. Krishnamurthy and Vissing-Jorgensen (2012). Banks buy Government bonds employing only their net profits. Simulation results do not change if Government debt is allocated to banks according to their profit shares instead of credit shares.

${ }^{11}$ As the model has been designed to account for both small fluctuation and big crises, we think that it is reasonable and in line with the current practices (see e.g. Bernanke, 2011) to let the Central Bank buy sovereign bonds, especially when banking crises force the Government to bailout banks, considerably increasing the public debt.
} 
tion in turn coincides with the sum of aggregate consumption, investment and change in inventories.

\section{Simulation Results}

The analysis of the properties of the model is performed via extensive Montecarlo simulations to wash away across-simulation variability. Consequently, all results below refer to across-run averages. ${ }^{12}$ Before studying the impact of fiscal austerity policies (cf. Section 3.3), we check whether in the "benchmark" setup the model is "empirically validated" (see Sections 3.1 and 3.2 ), i.e. it is able to account for a wide spectrum of macroeconomic and microeconomic stylized facts, in line with Dosi et al. (2006, 2008, 2010, 2013, 2014).

\subsection{Empirical Validation}

Let us start by considering how the model fares as to macroeconomic empirical regularities (much more details on these results in Dosi et al., 2010, 2013, 2014). First, self-sustained growth is endogenously generated by the model (see the top-left plot in Figure 2). Longrun output growth is fuelled by productivity increases, which result from capital-good firms' investment in R\&D and the diffusion of new vintages of equipment embodying the latest technologies in the consumption-good sector.

At the business cycle frequencies, macroeconomic series exhibit patterns akin to those found in real data (e.g. Stock and Watson, 1999; Napoletano et al., 2006). ${ }^{13}$ Considering the magnitude of fluctuations, investment is more volatile than GDP while consumption is less. The co-movements between macroeconomic variables show, in line with the empirical evidence, that consumption is pro-cyclical and coincident, net investment, changes in inventories, productivity, nominal wages and inflation are pro-cyclical; unemployment, prices and mark-ups are countercyclical (for the empirics and discussion cf. Stock and Watson, 1999).

Furthermore, the model also matches the major business cycle stylized facts concerning credit (as reported for instance by Bikker and Metzemakers, 2005) and banking crises. Indeed, firms' total debt and bank profits are pro-cyclical, while loan losses are countercyclical. Studies about credit dynamics (e.g. Mendoza and Terrones, 2012) have found that credit booms are often followed by banking or currency crises characterizing a boom-

\footnotetext{
${ }^{12}$ All the simulation results refers to 100 Montecarlo independent runs, each of them involving 600 time steps. Extensive tests show that the results are robust to changes in the initial conditions for the microeconomic variables of the model. In addition, they show that, for the statistics under study, Montecarlo distributions are sufficiently symmetric and unimodal. This justifies the use of across-run averages as meaningful synthetic indicators. All our results do not significantly change if the Montecarlo sample size is increased. The benchmark parameterization is presented in Dosi et al. (2014).

${ }^{13}$ The results concerning the empirical validation of the $\mathrm{K}+\mathrm{S}$ not presented here are available from the authors upon request.
} 

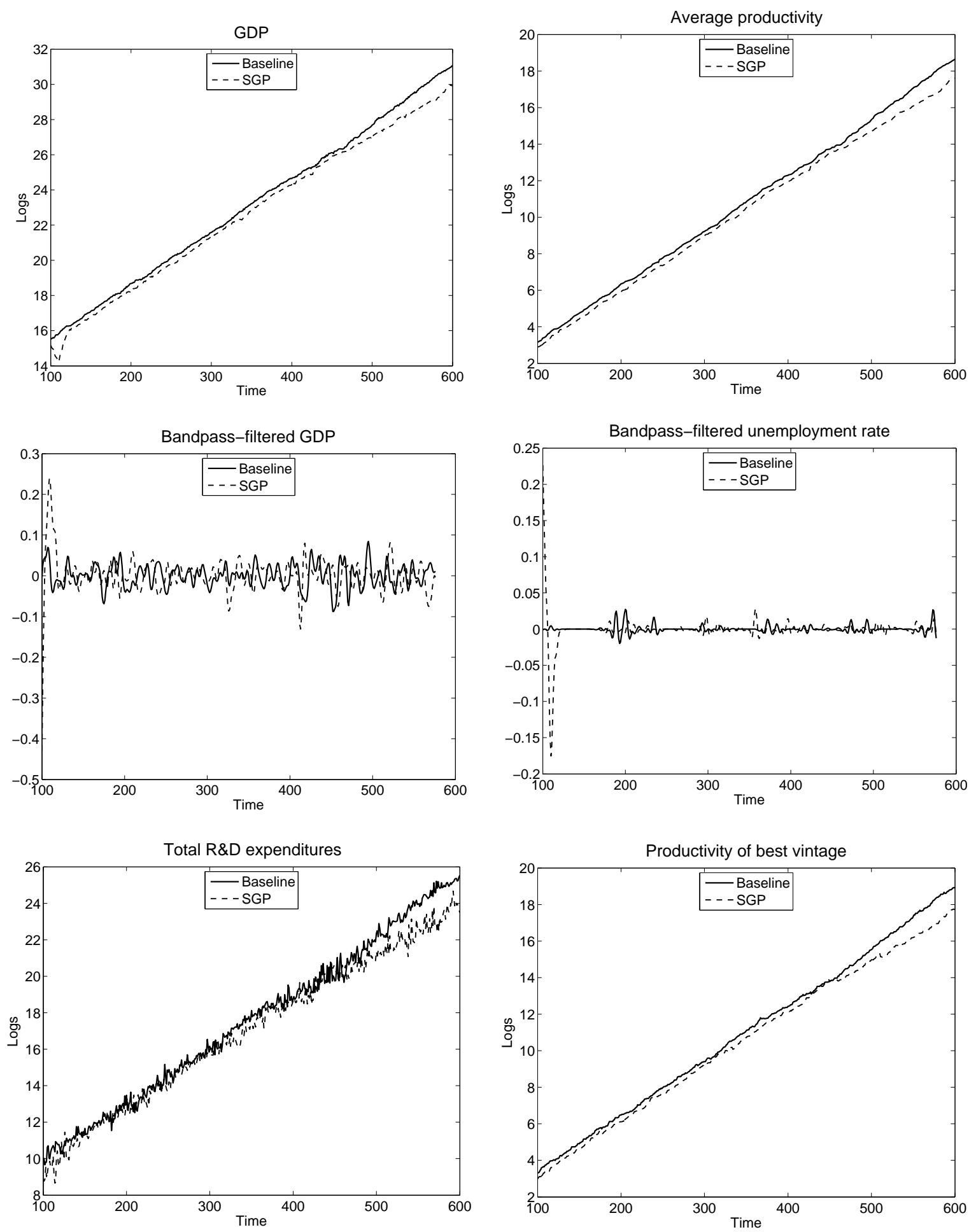

Figure 2: Model-generated macroeconomic series 
bust cycle. In line with such evidence, we find that higher levels of firm debt lead to higher firm default: bad debt is positively correlated with firm debt, with a lag. Loan growth thus entails higher default rates, further weakening banks' balance sheet (in line with the findings in Foos et al., 2010). Moving to stylized facts about banking crises (Laeven and Valencia, 2008; Reinhart and Rogoff, 2009), we find that the distribution of banking crisis duration closely tracks the empirical one, and again in tune with the empirical literature, the distribution of the ratio between fiscal costs of banking crises and GDP is characterized by excess kurtosis, with tails much heavier than those resulting from any normal distribution.

Finally, the model is also able to replicate several microeconomic empirical regularities. To begin with, firms are extremely heterogeneous in terms of size, growth rate and productivity: firm size distributions are right skewed; firm growth-rate distributions are fat tailed; productivity differentials among firms are persistent over time (see e.g. Bartelsman and Doms, 2000; Dosi, 2007). Moreover, firms invest in a lumpy fashion (Doms and Dunne, 1998) and firms' R\&D investment is pro-cyclical (see e.g. Walde and Woitek, 2004). Note that the capability of agent-based models to replicate both macro and micro stylized facts is one of the major advantages vis-à-vis DSGE ones, which by building on the fiction of the representative agent cannot account for any meaningful heterogeneity at the microeconomic level.

\subsection{Accounting for Mild and Deep Recessions}

Economic growth in the $\mathrm{K}+\mathrm{S}$ model is characterized by the spontaneous emergence of business cycles (see the bandpass-filtered GDP in Figure 2). Note that economic fluctuations of "normal times" are punctuated by few deep downturns. Indeed, the probability that the economy experiences a crisis (i.e. a fall of GDP higher than $3 \%$ ) is on average $6 \%$ (cf. the second column of Table 1). Moreover, in line with Ausloos et al. (2004), the large majority of economic crises are short-lived, lasting only one period, but few downturns have a long duration. As a consequence, the model-generated distribution of recession durations is exponential well in line with the empirical evidence (cf. Figure 3; and Wright, 2005, on the historical evidence). Finally, the GDP growth-rate distribution generated by the model exhibits fat tails (cf. Figure 4) well in tune with the empirical evidence (Fagiolo et al., 2008). Note that DSGE models are not able to match such empirical regularities even if they are fed with fat-tailed shocks (Ascari et al., 2014).

The K+S model is indeed a good candidate to provide an answer to Stiglitz's (2014a,b) plea for macroeconomic models able to jointly account for both mild recessions and big crises. What are the forces responsible for the emergence of major downturns in our model?

The Schumpeterian side of the model is at the root of endogenous growth but it also 


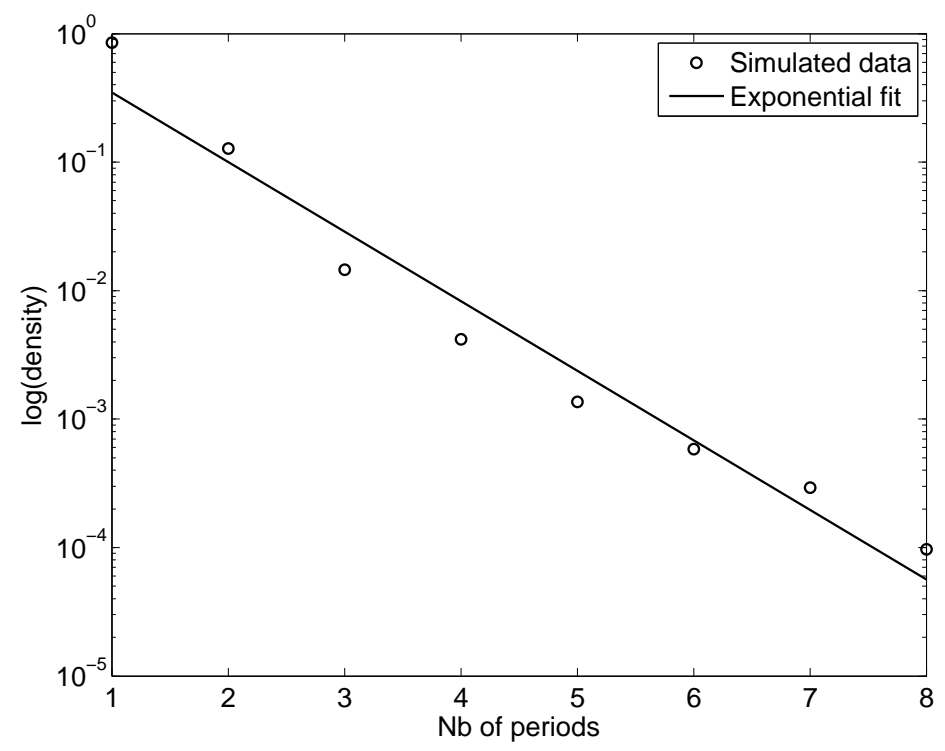

Figure 3: Duration of recessions: simulated data and exponential fit

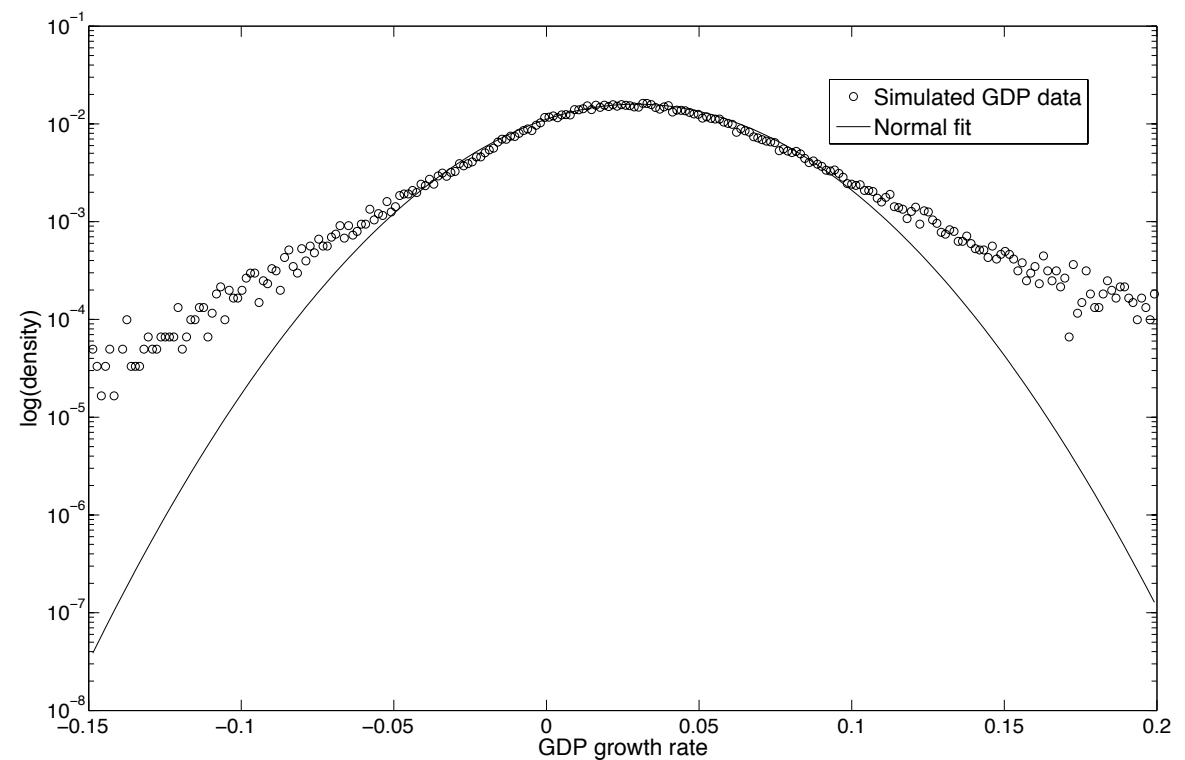

Figure 4: GDP growth-rate distribution: simulated data vs. Normal fit 


\begin{tabular}{lcc} 
Statistics & Baseline & SGP / Baseline \\
\hline \hline avg. GDP growth & 0.030 & $0.701^{*}$ \\
avg. productivity growth & 0.030 & $0.954^{*}$ \\
\hline avg. GDP volatility & 0.040 & $9.176^{*}$ \\
avg. unemployment rate & 0.041 & $3.439^{*}$ \\
share employment created & 0.132 & $1.086^{*}$ \\
share employment destroyed & 0.133 & $1.135^{*}$ \\
\hline avg. crisis likelihood & 0.060 & $1.484^{*}$ \\
avg. duration recessions & 1.235 & $1.165^{*}$ \\
max duration recessions & 4.020 & $2.169^{*}$ \\
\hline debt-to-GDP ratio & 0.040 & $+\infty$ \\
\hline \hline
\end{tabular}

Table 1: Economic performance under alternative fiscal policies. Montecarlo averages. (SGP): Structural and Growth Pact fiscal rule. $\left(^{*}\right)$ : the $H_{0}$ : "no difference between baseline and the SGP fiscal rule" is rejected at $1 \%$ level.

interacts with aggregate demand via firms' investment decisions. The latter in turn are determined by: i) firms' heterogeneous expectations about future (consumption) demand, and ii) firms' heterogeneous financial conditions. It is via production plans and investment that the Keynesian part of the model affects both the short- and long-run performance of the economy. Indeed, a lack of firm investment depresses aggregate demand, reducing output and increasing unemployment, but it also impacts on the long-run dynamics, as technological diffusion is slowed down in the downstream sector and capital-good firms invest a lower amount of resources in R\&D. Finally, in a truly Minskian vein, interactions between real and financial sectors can reinforce the aforementioned investment dynamics. Over-indebtedness of firms can trigger avalanches of firm failures (see also discussion in the previous section), thereby leading to banking crises and to the emergence of widespread credit-rationing. The interactions between the Schumpeterian and Keynesian engines of growth (or stagnation) are even more neatly put in evidence in the fiscal policy experiments that we discuss in the next section.

\subsection{Fiscal Policy Experiments}

In the baseline scenario discussed so far, fiscal policy is not constrained: taxes and unemployment subsidies act as automatic stabilizers, and thus dampen business cycles fluctuations without being limited by Government deficit. ${ }^{14}$ We now compare the short- and long-run performance of the economy in the benchmark scenario with the one emerging when a fiscal rule mirroring the conditions of the European Stability and Growth Pact

\footnotetext{
${ }^{14}$ McKay and Reis (2013) find that automatic stabilizers can strongly contribute to dampen business cycle volatility, especially through the redistribution and social-insurance channels. See also Solow (2005) and Blanchard et al. (2010) on the case for stronger automatic stabilizers as a tool for better macroeconomic policy.
} 
(SGP) is in place. With a SGP fiscal rule, the Government ought to reach a public deficit target equal to:

$$
D e f_{t} \leq \operatorname{de}_{\text {rule }} G D P_{t-1}
$$

with de $f_{\text {rule }}=0.03$ being the maximum value of the deficit to GDP ratio allowed. When the rule is binding, the Government has to reduce the amount of subsidies distributed in the period $\left(G_{t}\right){ }^{15}$

How does the SGP austerity rule affect the short- and long run performance of the economy? The results of the experiments are presented in Figure 2 and in Table 1. In the third column of Table 1, we report the ratio between the Montecarlo average of the macroeconomic variables under the SGP rule and the ones generated by the baseline scenario with unconstrained fiscal policy.

Let's first begin with the short-run dynamics. The introduction of the SGP fiscal rule strongly magnifies the fluctuations of the economy and it triples the average unemployment rate. The greater turbulence in the economic system spurs both employment creation and destruction (cf. Table 1). Moreover, austerity rules increase the duration of recessions and the probability of deep downturns. The dismal macroeconomic performance under the SGP rule leads to an explosion of the ratio between public debt and GDP. As a consequence, fiscal-consolidation policies appear to be self-defeating (cf. Table 1), in line with the empirical evidence (Guajardo et al., 2011; Blanchard and Leigh, 2013). The catastrophic macroeconomic consequences associated to austerity policies are due to the strict limit that such rules impose on Government deficit during recession periods, when the smoothing effects of automatic stabilizers are the most needed (McKay and Reis, 2013). This further depresses aggregate demand and exacerbates the fall of output, ultimately increasing the ratio between sovereign debt and GDP. ${ }^{16}$

We now consider whether the disastrous short-run impact of austerity policies affect also the long-run performance of the economy by undermining its growth potential. In Figure 2, we plot the time series of GDP for both the baseline and SGP scenarios. The dashed line showing the evolution of the (log of) real GDP in the SGP scenario is always below the corresponding line in the baseline scenario (solid line). This suggests the negative effects of austerity rule are permanent (see also Table 1 comparing the average GDP growth rate in the SGP case with the baseline one). Ultimately, the "Keynes to Schumpeter feedback mechanism" appears to be responsible for such result, as the fiscal-consolidation rule significantly slows down productivity growth. ${ }^{17}$

\footnotetext{
${ }^{15}$ If the deficit rule is binding, the Government, as unfortunately occurs too often in the real world, sets as priority the bailout of banks before the payment of unemployment subsidies, which have to be reduced to satisfy the $3 \%$ deficit condition. However, after all unemployment subsidies have been cut, the Government still might not be able to respect the $3 \%$-deficit target.

${ }^{16}$ The simulation results are robust also when we assume a positive correlation between public debt to GDP levels and bond yields, adding a risk premium to the interest rate on sovereign bonds.

${ }^{17}$ Note that in the SGP scenario, the rate of productivity growth is higher than the GDP one. This is explained by the fact that we exclude the possibility of technological regress in the model (firms do
} 
What are the underlying microeconomic dynamics explaining the above results? By curbing aggregate demand during recessions, the introduction of the SGP reinforces (instead of dampening) the fall of the investment rate responsible for the downturn. This slows down the diffusion of machine-tools with the latest technology. Moreover, as capitalgood firms face shrinking sales, they cut their R\&D investment plans (cf. Figure 2). This hinders the innovation rate of the economy. The joint reduction of new technology creation and diffusion implies that the best vintage stays undisputed for a longer period, and the productivity frontier evolves more slowly (see Figure 2). Finally, the slower pace of technological change reduces the replacement investment of consumption-good firms, thus contributing to further depress aggregate demand and the innovation rate in the economy.

To sum up, austerity policies trigger a vicious cycle that traps the economy in a stagnant equilibrium, characterized by anemic output growth, slow technological change, and higher economic instability. In addition, they imply high levels of unemployment and an explosion in the public debt to GDP ratio.

\section{Concluding Remarks}

We have employed the Keynes+Schumpeter agent-based model (Dosi et al., 2010, 2013, 2014) to explore the effects of fiscal rules mimicking the European Stability and Growth Pact (SGP).

Simulation results show that austerity policies have strong and negative effects on the performance of economy both in the short- and long-run. More specifically, when the fiscal rule is in place, the economy is more volatile, unemployment is higher and deep downturns are more frequent and longer than in the benchmark scenario, where Keynesian fiscal policies are free to dampen business cycle fluctuations. This carries long-term effects as austerity policies lead to lower investment in $R \& D$ and slower technological diffusion, thus reducing the innovative capabilities of the economy and depressing productivity and output growth.

Such dire results are not even partially compensated by the stabilization of the public budget: fiscal-consolidation policies appear to be self-defeating (in line with a growing empirical evidence, e.g. De Grauwe and Ji, 2013), as they lead to the explosion of the public debt to GDP ratio. Austerity policies turn out to be recipes for disasters also in terms of public finances, which they are purportedly designed to save!

\section{Acknowledgments}

We are grateful for helpful comments and discussions by Uwe Cantner, Tommaso Ciarli, Mario

not scrap machines if they cannot replace them). In such case, our results about the negative long-run effects of austerity policies would be reinforced. 
Cimoli, Herbert Dawid, Jean-Luc Gaffard, Co-Pierre Georg, Cars Hommes, Peter Howitt, Antoine Mandel, Joao Basilio Pereima, Gabriel Porcile, Marco Raberto, Xavier Ragot, Pier Paolo Saviotti, Oreste Tristani, Marco Valente, Murat Yıldızoğlu, and several participants at seminars and conferences where the paper has been presented and in particular at the International Economic Association's Seventeenth World Congress, Jordan, June 2014. All usual disclaimers apply. The authors gratefully acknowledge the financial support of the Institute for New Economic Thinking (INET) grants \#220, "The Evolutionary Paths Toward the Financial Abyss and the Endogenous Spread of Financial Shocks into the Real Economy" and INO12-00039, "INET Task force in Macroeconomic Efficiency and Stability".

\section{References}

Adrian, T. and H. Shin (2010), "Financial Intermediaries and Monetary Economics", Staff Reports 398, Federal Reserve Bank of New York.

Akerlof, G. A. (2002), "Behavioral Macroeconomics and Macroeconomic Behavior", American Economic Review, 92: 411-433.

Alesina, A. and S. Ardagna (2010), "Large Changes in Fiscal Policy: Taxes Versus Spending", NBER Chapters, in: Tax Policy and the Economy, 24: 35-68.

Ascari, G., G. Fagiolo and A. Roventini (2014), "Fat-Tail Distributions and Business-Cycle Models", Macroeconomic Dynamics, FirstView: 1-12.

Ashraf, Q., B. Gershman and P. Howitt (2011), "Banks, Market Organization, and Macroeconomic Performance: an Agent-Based Computational Analysis", Working Paper 17102, National Bureau of Economic Research.

Auerbach, A. and Y. Gorodnichenko (2012), "Measuring the Output Responses to Fiscal Policy", American Economic Journal: Economic Policy, 4: 1-27.

Ausloos, M., J. Miskiewicz and M. Sanglier (2004), "The Durations of Recession and Prosperity: Does their Distribution Follow a Power or an Exponential Law?", Physica A: Statistical Mechanics and its Applications, 339: 548-558.

Bartelsman, E. and M. Doms (2000), "Understanding Productivity: Lessons from Longitudinal Microdata", Journal of Economic Literature, 38: 569-94.

Battiston, S., D. Delli Gatti, M. Gallegati, B. Greenwald and J. Stiglitz (2012), "Liaisons Dangereuses: Increasing Connectivity, Risk Sharing, and Systemic Risk", Journal of Economic Dynamics and Control, 36: 1121-1141.

Becker, B. and V. Ivashina (2014), "Cyclicality of Credit Supply: Firm Level Evidence", Journal of Monetary Economics, forthcoming.

Berger, A. N., A. K. Kashyap, J. M. Scalise, M. Gertler and B. M. Friedman (1995), "The Transformation of the US Banking Industry: What a Long, Strange Trip it's Been", Brookings Papers on Economic Activity, 1995: 55-218.

Bernanke, B. (2011), "The Effects of the Great Recession on Central Bank Doctrine and Practice", Speech at the Federal Reserve Bank of Boston 56th Economic Conference,.

Bikker, J. and P. Metzemakers (2005), "Bank Provisioning Behaviour and Procyclicality", International Financial Markets, Institutions and Money, 15: 141-157. 
Blanchard, O., G. Dell'Ariccia and P. Mauro (2010), "Rethinking Macroeconomic Policy", Journal of Money, Credit and Banking, 42: 199-215.

Blanchard, O. J. and D. Leigh (2013), "Growth Forecast Errors and Fiscal Multipliers", Working Paper 18779, National Bureau of Economic Research.

Caves, R. (1998), "Industrial Organization and New findings on the Turnover and Mobility of Firms", Journal of Economic Literature, 36: 1947-1982.

Ciarli, T., A. Lorentz, M. Savona and M. Valente (2010), "The Effect of Consumption and Production Structure on Growth and Distribution. A Micro to Macro Model", Metroeconomica, 61: $180-218$.

Dawid, H. and G. Fagiolo (eds.) (2008), Special Issue on "Agent-Based Models for Economic Policy Design", In Journal of Economic Behavior \& Organization, vol. 67.

Dawid, H., S. Gemkow, P. Harting, S. van der Hoog and M. Neugart (2014a), "Agent-Based Macroeconomic Modeling and Policy Analysis: The Eurace@Unibi Model", in S.-H. Chen and M. Kaboudan, (eds.), Handbook on Computational Economics and Finance, Oxford University Press.

Dawid, H., P. Harting and M. Neugart (2014b), "Economic Convergence: Policy Implications from a Heterogeneous Agent Model", Journal of Economic Dynamics and Control, http://dx.doi.org/10.1016/j.jedc.2014.04.004.

De Grauwe, P. and Y. Ji (2013), "Self-Fulfilling Crises in the Eurozone: an Empirical Test", Journal of International Money and Finance, 34: 15-36.

Delli Gatti, D., M. Gallegati, B. Greenwald, A. Russo and J. Stiglitz (2010), "The Financial Accelerator in an Evolving Credit Network", Journal of Economic Dynamics and Control, 34: $1627-1650$.

Doms, M. and T. Dunne (1998), "Capital Adjustment Patterns in Manufacturing Plants", Review Economic Dynamics, 1: 409-29.

Dosi, G. (2007), "Statistical Regularities in the Evolution of Industries. A Guide through some Evidence and Challenges for the Theory", in F. Malerba and S. Brusoni, (eds.), Perspectives on Innovation, Cambridge MA, Cambridge University Press.

Dosi, G. (2012), "Economic Coordination and Dynamics: Some Elements of an Alternative 'Evolutionary' Paradigm", in Economic Organization, Industrial Dynamics and Development, Selected Essays, Vol. 2, Edward Elgar Publishing, Cheltenham, UK, Northampton, MA, USA.

Dosi, G., G. Fagiolo, M. Napoletano and A. Roventini (2013), "Income Distribution, Credit and Fiscal Policies in an Agent-Based Keynesian Model", Journal of Economic Dynamics 83 Control, 37: 1598-1625.

Dosi, G., G. Fagiolo, M. Napoletano, A. Roventini and T. Treibich (2014), "Fiscal and Monetary Policies in Complex Evolving Economies", Journal of Economic Dynamics \& Control, forthcoming.

Dosi, G., G. Fagiolo and A. Roventini (2006), "An Evolutionary Model of Endogenous Business Cycles", Computational Economics, 27: 3-34.

Dosi, G., G. Fagiolo and A. Roventini (2008), "The Microfoundations of Business Cycles: an Evolutionary, Multi-Agent Model", Journal of Evolutionary Economics, 18: 413-432. 
Dosi, G., G. Fagiolo and A. Roventini (2010), "Schumpeter Meeting Keynes, a Policy-Friendly Model of Endogenous Growth and Business Cycles", Journal of Economic Dynamics and Control, 34: 1748-1767.

Ennis, H. (2001), "On the Size Distribution of Banks", FRB Richmond Economic Quarterly, 87: $1-25$.

Fagiolo, G., M. Napoletano and A. Roventini (2008), "Are Output Growth-Rate Distributions Fat-Tailed? Some Evidence from OECD Countries", Journal of Applied Econometrics, 23: 639-669.

Fagiolo, G. and A. Roventini (2012), "Macroeconomic Policy in Agent-Based and DSGE Models", Revue de l'OFCE, 124: 67-116.

Farmer, J. D. and D. Foley (2009), "The Economy Needs Agent-Based Modelling", Nature, 460: 685-686.

Ferraresi, T., A. Roventini and G. Fagiolo (2014), "Fiscal Policies and Credit Regimes: A TVAR Approach", Journal of Applied Econometrics, forthcoming.

Foos, D., L. Norden and M. Weber (2010), "Loan Growth and Riskiness of Banks", Journal of Banking and Finance, 34: 2929-2940.

Gaffard, J.-L. and M. Napoletano (eds.) (2012), Agent-Based Models and Economic Policy, volume 124 of Revue de l'OFCE. Debates and Policies, OFCE.

Godley, W. and M. Lavoie (2007), Monetary economics: An integrated approach to credit, money, income, production and wealth, Palgrave Macmillan.

Greenwald, B. and J. Stiglitz (1986), "Externalities in Economies with Imperfect Information and Incomplete Markets", Quarterly Journal of Economics, 101: 229-264.

Greenwald, B. and J. Stiglitz (1993), "Financial Market Imperfections and Business Cycles", Quarterly Journal of Economics, 108: 77-114.

Guajardo, J., D. Leigh and A. Pescatori (2011), "Expansionary Austerity : New International Evidence", Working Paper Research Department WP/11/158, International Monetary Fund.

Herndon, T., M. Ash and R. Pollin (2014), "Does High Public Debt Consistently Stifle Economic Growth? A Critique of Reinhart and Rogoff", Cambridge Journal of Economics, 38: 257-279.

Howitt, P. (1992), "Interest Rate Control and Nonconvergence to Rational Expectations", Journal of Political Economy, 100: 776-800.

Hubbard, G. R. (1998), "Capital-Market Imperfections and Investment", Journal of Economic Literature, 36: 193-225.

Kaldor, N. (1955), "Alternative Theories of Distribution", The Review of Economic Studies, : $83-100$.

Kirman, A. P. (2010a), Complex Economics. Individual and Collective Rationality, Routledge: London.

Kirman, A. P. (2010b), "The Economic Crisis is a Crisis for Economic Theory", CESifo Economic Studies, 56. 
Krishnamurthy, A. and A. Vissing-Jorgensen (2012), "The Aggregate Demand for Treasury Debt", Journal of Political Economy, 120: 233-267.

Krugman, P. (2011), "The Profession and the Crisis", Eastern Economic Journal, 37: 307-312.

Laeven, L. and F. Valencia (2008), "Systemic Banking Crises: A New Database", Working Paper WP/08/224, International Monetary Fund.

LeBaron, B. and L. Tesfatsion (2008), "Modeling Macroeconomies as Open-Ended Dynamic Systems of Interacting Agents", American Economic Review, 98: 246-250.

Mandel, A., C. Jaeger, S. Fuerst, W. Lass, D. Lincke, F. Meissner, F. Pablo-Marti, S. Wolf et al. (2010), "Agent-Based Dynamics in Disaggregated Growth Models", CES Working Paper 2010.77, Université Paris 1 Panthéon Sorbonne.

McKay, A. and R. Reis (2013), "The Role of Automatic Stabilizers in the U.S. Business Cycle", Working Paper 19000, National Bureau of Economic Research.

McLeay, M., R. Amar and T. Ryland (2014), "Money Creation in the Modern Economy", Bank of England Quarterly Bulletin, 54: 14-27.

Mendoza, E. and M. Terrones (2012), "An Anatomy of Credit Booms and their Demise", Working Paper 18379, National Bureau of Economic Research.

Modigliani, F. and M. Miller (1958), "The Cost of Capital, Corporation Finance and the Theory of Investment", American Economic Review, 48: 261-97.

Myers, S. (1984), "The Capital Structure Puzzle", The Journal of Finance, 39: 575-592.

Napoletano, M., G. Dosi, G. Fagiolo and A. Roventini (2012), "Wage formation, investment behavior and growth regimes: An agent-based analysis", Revue de l'OFCE, 124: 235-261.

Napoletano, M., A. Roventini and S. Sapio (2006), "Are Business Cycles All Alike? A Bandpass Filter Analysis of the Italian and US Cycles", Rivista Italiana degli Economisti, 1: 87-118.

Nelson, R. R. and S. G. Winter (1982), An Evolutionary Theory of Economic Change, Cambridge, The Belknap Press of Harvard University Press.

Phelps, E. S. and S. G. Winter (1970), "Optimal Price Policy under Atomistic Competition", in E. S. Phelps, (ed.), Microeconomic Foundations of Employment and Inflation Theory, New York, Norton.

Raberto, M., A. Teglio and S. Cincotti (2012), "Debt, Deleveraging and Business Cycles: An Agent-Based Perspective", Economics-The Open-Access, Open-Assessment E-Journal, 6: $2011-31$.

Reinhart, C. and K. Rogoff (2009), "The Aftermath of Financial Crises", Working Paper 14656, National Bureau of Economic Research.

Reinhart, C. M. and K. S. Rogoff (2010), "Growth in a Time of Debt", American Economic Review, 100: 573-578.

Rotemberg, J. (2008), "Behavioral Aspects of Price Setting, and Their Policy Implications", Working Paper 13754, National Bureau of Economic Research. 
Russo, A., M. Catalano, M. Gallegati, E. Gaffeo and M. Napoletano (2007), "Industrial Dynamics, Fiscal Policy and R\&D: Evidence from a Computational Experiment", Journal of Economic Behavior \&S Organization, 64: 426-447.

Salle, I., M. Yıldızoğlu and M.-A. Sénégas (2013), "Inflation Targeting in a Learning Economy: an ABM Perspective", Economic Modelling, 34: 114 - 128.

Solow, R. M. (2005), "Rethinking Fiscal Policy", Oxford Review of Economic Policy, 21: 509514.

Solow, R. M. (2008), "The State of Macroeconomics", Journal of Economic Perspectives, 22: 243-246.

Stiglitz, J. (2014a), "Reconstructing Macroeconomic Theory to Manage Economic Policy", Working Paper 20517, NBER.

Stiglitz, J. (2014b), "Towards a General Theory of Deep Downturns", International Economic Association Presidential Address.

Stiglitz, J. and A. Weiss (1981), "Credit Rationing in Markets with Imperfect Information", The American Economic Review, 71: 393-410.

Stiglitz, J. E. (2011), "Rethinking macroeconomics: what failed, and how to repair it", Journal of the European Economic Association, 9: 591-645.

Stock, J. and M. Watson (1999), "Business Cycle Fluctuations in U.S. Macroeconomic Time Series", in J. Taylor and M. Woodford, (eds.), Handbook of Macroeconomics, Elsevier, 3-64.

Taylor, J. (1993), "Discretion versus Policy Rules in Practice", Carnegie-Rochester Series on Public Policy, 39: 195-214.

Tesfatsion, L. and K. L. Judd (eds.) (2006), Handbook of Computational Economics, Volume 2: Agent-based Computational Economics, North-Holland.

Walde, K. and U. Woitek (2004), "R\&D Expenditure in G7 Countries and the Implications for Endogenous Fluctuations and Growth", Economic Letters, 82: 91-97.

Wolff, E. N. (1998), "Recent Trends in the Size Distribution of Household Wealth", Journal of Economic Perspectives, 12: 131-150.

Wright, I. (2005), "The Duration of Recessions Follows an Exponential not a Power Law", Physica A: Statistical Mechanics and its Applications, 345: 608-610. 